\title{
Tectonic foliations and the distribution of landslides in the southern Central Range, Taiwan
}

Chung Huang ${ }^{1,2, *}$, Timothy B. Byrne ${ }^{1}$, William B. Ouimet ${ }^{1}$, Ching-Weei Lin ${ }^{3}$, Jyr-Ching $\mathrm{Hu}^{2}$, Li-Yuan $\mathrm{Fei}^{4}$, and Yu-Bo Wang ${ }^{5}$

${ }^{1}$ Center for Integrative Geosciences, University of Connecticut, Storrs, Connecticut 06269-1045, United States

${ }^{2}$ Department of Geosciences, National Taiwan University, Daan District, Taipei City 10617, Taiwan

${ }^{3}$ Department of Earth Sciences, National Cheng Kung University, East District, Tainan City 70101, Taiwan

${ }^{4}$ Central Geological Survey, Ministry of Economic Affairs, R.O.C., Zhonghe District, New Taipei City 23568, Taiwan

${ }^{5}$ Department of Statistics, University of Connecticut, Storrs, Connecticut 06269-4120, United States

* Corresponding author. Department of Geosciences, National Taiwan University, Number 1, Section 4, Roosevelt Road, Daan District, Taipei City 10617, Taiwan. Tel: +886-2-3366-4956\#310, Fax: +886-2-2364-4625

E-mail: chunghuang@ntu.edu.tw 


\section{INTRODUCTION}

Landslides can be triggered by earthquakes, strong rainfall, or melting snow (Dadson et el., 2004; Del Gaudio et al., 2003; Del Gaudio and Wasowski, 2004; Huang et al., 2001; Jibson, 1996; Jibson and Keefer, 1989; Lin et al., 2011a; Romeo, 2000; Wieczorek, 1996). The distribution of landslides in a particular area, however, can also be influenced by the local strength of the rocks or geological structures (Chen et al., 2009; Guzzetti et al., 2008a). For example, steep hill slopes are more susceptible to failure even in the absence of external events. Slopes that are parallel to a planer fabric within any coherent rock like bedding or other planner structures, defining a dip slope, can also make catastrophic landslides (Chang et al., 2005; Chen et al., 2005a; Hung, 2000; Tang et al., 2009).

Typically, dip slope failure is caused by the failure of a weak bedding surface in sedimentary rock layers, however, any planner geological structure within a rock may induce failure (Chigira, 1992). In this study, we demonstrate that tectonic foliation plays an important role in slope failure similar to weak bedding planes in a sedimentary rock.

To understand how tectonic foliations influences dip slope failure, we compiled data from the southern Central Range of Taiwan where this area has 1) good coverage 
of structure fabric measurements, 2) abundant landslides caused in part by heavy rainfall, and 3) a new series of aerial photos and satellite images taken for the purpose of landslide mapping.

Beside hill slope and precipitation, here, we propose that the tectonic foliation is also an important factor that influences the distribution of landslides in regions of the southern Central Range where slate is the dominant rock type. The southern Central Range exposes two main rock types: slate and schist. Based on mapping and the analyses presented here, landslides tend to occur in the dip slope areas of regions dominated by slate and in the scarp slope areas in regions dominated by schist. We propose that the landslide pattern is a result of different anisotropies in rocks with different degrees of metamorphism. Slate has a better developed anisotropy which appears to provide a weaker failure plane compared to the schist, so the dip slope failure is more common in the slate region of the southern Central Range of Taiwan.

\section{STUDY AREA AND GEOLOGICAL SETTING}

The southern Central Range represents the southern extent of the Taiwan arc-continental collision, which sits on a convergent boundary between Philippine Sea and Eurasian Plates with a relatively high convergence rate of $82 \mathrm{~mm}$ per year since 5 Ma (Teng, 1990; Yu et al., 1997, see Figure 1). There are two tectonostratigraphic units 
in the study area that can be divided into three rock units. The two tectonostratigraphic units are the Tananao Metamorphic Complex and the Central Range slate belt. The Tananao Metamorphic Complex is composed of pre-Tertiary metamorphic rocks, dominantly gray, black and green schists that display two or more rough cleavages. The slate belt is composed of two sub-belts; an Eocene belt and a Miocene belt. The Eocene slate belt crops out east and west of the schist, whereas the Miocene slate encompasses both the Eocene slate and the schist (Ho, 1986. see Figure 2).

The three rock units have different degrees of cleavage devolvement. The Miocene slate has the lowest peak metamorphic temperature of the three units and the cleavage in this unit changes from north to south. The cleavage in the northern part of the Miocene slate is a penetrative cleavage whereas in the southern part of the belt the rocks display a pencil cleavage (Chen et al., 2005b; Ho, 1986; Huang and Byrne, 2014; Lin, 1999; Lin et al., 2011b; Sung 1991; Sung et al., 2000). The Eocene slate belt records a moderate grade (e.g., lower greenschist facies) of metamorphism and displays a well-developed penetrative cleavage; even relatively thick meta-sandstones and meta-conglomerates in this belt are penetratively deformed (Lee, 1977; Ho, 1986). The Eocene slate occupies most of the ridge crest in the southern Central Range, and it suggests that the rock strength is the highest of the three units (Dadson et al., 2003). The schist belt is located east of the ridge crest and displays multiple cleavages, including a 
late crenulation cleavage that generally dips to the northwest, which is opposite the dip direction of the cleavage in the Eocene and Miocene slate units to the west.

The geometry of tectonic foliation in the study area can be grouped into two major domains based on the dominant dip direction: northwest and southeast (Figure 3). The northwest-dipping domain is mainly distributed east of the ridge crest, including most of the schist and Eocene slate. The southeast-dipping domain is mainly distributed west of the ridge crest and the southern part of the study area, including Eocene and Miocene slate. The geometry of the tectonic foliation in these two domains has been described as a fanning structure, and could be a result of post-cleavage deformation (Crespi et al., 1996; Fisher et al., 2007).

The study area covers $4795.4 \mathrm{~km}^{2}$ and includes all the southern Central Range south of the South-Cross-Island-Highway (SXIH). The ridge crest runs approximately north-south south of Mt. Guan (highest peak in the study area at 3,668 m) and then turns to northeast-southwest north of Mt. Guan (Figure 4).

The Central Geological Survey of Taiwan has recognized 38,686 landslides in the study area, with 36,664 of these occurring in the slate and 2,022 in the schist. A $\log -\log$ plot with a $10^{0.2}$ bin width of the landslides in the field area (Figure 5) shows the size distribution of landslides in areas dominated by either slate or schist. The 
smallest landslide in areas underlain by slate is $103 \mathrm{~m}^{2}$ and the largest is $1,296,984$ $\mathrm{m}^{2}$; while the smallest landslide in areas underlain by schist is $123 \mathrm{~m}^{2}$ and largest is $889,252 \mathrm{~m}^{2}$. Both of the plots show that landslide densities decrease at $630 \mathrm{~m}^{2}$, suggesting that the different lithological units in southern Taiwan have not influenced the size of landslides. These distributions are similar to a post-Morakot landslide size distribution plot of southern Taiwan by Lin et al. (2011a) and to the distribution of landslides triggered by different events in other places of Taiwan and the world (Hovius et al., 2000; Malamud et al., 2004; Stark and Guzzetti, 2009; Stark and Hovius, 2001).

\section{METHOD}

The landslides analyzed in this study are from a landslide catalog made by the Central Geological Survey of Taiwan. The coverage of this catalog is island wide and contains landslide polygons and their areas (in $\mathrm{m}^{2}$ ), a description of the method used to identify landslides via aerial photos or satellite image, and the coordinates of the centroid point of each landslide (Lin et al., 2010; Lin et al., 2011c; Lin et al., 2012). The resolution of the aerial photos is $50 \mathrm{~cm}$, and $8 \mathrm{~m}$ for satellite images. The satellite images were taken by the FORMOSAT-2 satellite which carries multispectral sensor covering wavelength from visible to near-infrared (Lin et al., 2011a). The landslides 
are manually selected by identifying the non-vegetated areas in the aerial photos and by using normalized difference vegetation index (NDVI) method (Lin et al., 2010; Lin et al., 2011c; Lin et al., 2012) to determine the non-vegetated areas in the satellite images.

The aerial photos and satellite images in the study area were taken at two different times: before and after the typhoon Morakot which arrived in Taiwan on 8 August 2009. The aerial photos in the northeastern part of slate region were taken before typhoon Morakot, the photos in the western and southern area of the slate were taken after typhoon Morakot, and the aerial photos in the schist region were taken before the typhoon Morakot. Some areas in the southern Central Range were not covered by aerial photos, so the Central Geological Survey use satellite images that were taken after typhoon Morakot to cover those areas.

To understand the relation between the distribution of landslides and tectonic foliation, we compared the hill slope direction with cleavage dip direction at the centroid point location of each inventoried landslide. In this study, we use $\theta_{\mathrm{D}}$ to define the angle between the direction of hill slope and the direction of cleavage dip. The hill slope direction is calculated from a 40m grid digital elevation model (DEM, see Figure 4) by the Spatial Analyst Tool of ArcGIS 10.2. The DEM was created by the Center for Space and Remote Sensing Research at National Central University in 
Taiwan, and the dip directions of cleavage were compiled from available geological maps and other field-based investigation reports ( $\mathrm{Hu}$ and Liu, 1987; Huang and Byrne, 2014; Lee, 1977; Lin et al., 2011b; Lin, 1999; Sung, 1991; Sung et al., 2000). We use the Spatial Analyst Tool of ArcGIS to construct two grids using the inverse distance weighted (IDW) method; one grid shows the cleavage dip azimuths (Figure 3) while the other shows the hill slope dip azimuth (Figure 6). The grid of cleavage dip azimuth was constructed with $5 \mathrm{~km}$ node interval, and the grid of hill slope dip azimuth was constructed with $80 \mathrm{~m}$ node interval. The $5 \mathrm{~km}$ interval for cleavage dip direction is the maximum average distance between cleavage measurement points with the same dip direction. The $80 \mathrm{~m}$ interval for slope direction is the result of program's computation limit because the number of grids exceeds the program's memory allocation limitation when the grid interval is less than $80 \mathrm{~m}$. We then subtracted the grid of cleavage dip azimuth by the grid of hill slope azimuth, which yielded a preliminary $\theta_{\mathrm{D}}$. (see Figure 7).

If the absolute value of azimuth is larger than $180^{\circ}$, we then subtracted the angle by $180^{\circ}$. After calculating the $\theta_{\mathrm{D}}$ value of each grid, we constructed another grid representing $\theta_{\mathrm{D}}$ with a resolution of $80 \mathrm{~m}$. In this grid, a dip slope occurs when $\theta_{\mathrm{D}}$ is 0 , and a scarp slope occurs when the $\theta_{\mathrm{D}}$ is $180^{\circ}$ (Figure 8 ). 
We then analyze the frequency of $\theta_{\mathrm{D}}$, hill slope, and tectonic foliation dip magnitude in the whole area and landslide areas in two lithological regions. In addition to the frequency of landslides, we also compare the landslide density $\left(D_{L}\right)$ in two dominant rock types: slate and schist (Figure 10). Landslide density is the percentage of area covered by landslides in each bin of $\theta_{\mathrm{D}}$, slope magnitude, or dip magnitude of tectonic foliation, (see e.g., Guzzetti et al., 2008b). We also considered the distribution of landslides of different sizes. Large size landslides are usually related to the failure of planner geological structures (Hung, 2000; Tang et al., 2009), so we not only analyze all landslides in each rock type region, but also analyzed the landslides that areas are larger than $630 \mathrm{~m}^{2}$. Finally, we compare the distribution of landslides to annual precipitation in the southern Central Range.

An example of using $\theta_{\mathrm{D}}$ in the slate region is shown in the Figure 9. The cleavage generally dips southeast in this area, and higher $\theta_{\mathrm{D}}$ values are distributed on the northwest-facing slopes, and lower $\theta_{D}$ values are distributed in the southeast-facing slopes. The landslides are mostly distributed in the southeast-facing slopes which are consistent with the locations of lower $\theta_{\mathrm{D}}$ value because the cleavage generally dips southeast in this area. The northwest-facing slopes in the central part of the image (encompassed by the blue area) have only a couple of small landslides on 
them, and it shows that steeper hill slopes are not necessary associated with large number of landslides.

\section{RESULTS}

The distribution of landslides associated with different $\theta_{\mathrm{D}}$ values, as shown in the histograms (Fig 10 and 11), show important patterns for understanding landslides in metamorphic terranes. For example, in areas underlain by slate, landslides are more common at low $\theta_{\mathrm{D}}$ values (e.g. less than $90^{\circ}$ ) than at high values for all landslides inventoried and for landslides larger than $630 \mathrm{~m}^{2}$ (Figure 10A). That is, landslides appear to form preferentially in areas where the topographic slope and cleavage dip directions are sub-parallel. A similar relation to $\theta_{\mathrm{D}}$ is also observed when considering the area covered by landslides rather than just the presence or absence of a landslide; that is, landslides cover more area at moderate $\theta_{\mathrm{D}}$ values (e.g., $30^{\circ}$ to $60^{\circ}$ ) for both all landslides inventoried and for larger landslides (Figure 10B). In contrast, in regions underlain by schist, landslides (both all landslides and large landslides) are more common in areas with high $\theta_{\mathrm{D}}$ values where the slope and cleavage dip in opposite directions (Figure 11A). The area covered by landslides also shows a slightly higher percentage of landslides at high $\theta_{\mathrm{D}}$ values, although the difference in area covered by landslides at high and low values of $\theta_{\mathrm{D}}$ is relatively small (Figure 11B). 
The distribution of landslides with different slope magnitude and cleavage dips shows a different pattern compared to the histograms of $\theta_{\mathrm{D}}$. There is also more consistency in the results between the different rock types and cleavage fabrics. For areas underlain by both slate and schist (and for landslides of different sizes) landslides occur more frequently at moderate slopes (e.g., $20^{\circ}$ to $40^{\circ}$ ) and more area is covered by landslides at higher slopes than at lower slopes (Figure 12 and 13), except for a small decrease at very high slopes (Figure 12B) in areas underlain by slate. The distribution of landslides with different tectonic foliation dips is similar with most landslides occurring at moderate foliation dips (Figure 14 and 15). Landslides in areas underlain by schist, however, appear to be more localized at slightly higher foliation dips; that is, $40^{\circ}$ to $50^{\circ}$ compared to $20^{\circ}$ to $30^{\circ}$ (Figure $15 \mathrm{~A}$ ). Interestingly, there appears to be no correlation between the size of landslides $\left(\mathrm{D}_{\mathrm{L}}\right)$ and tectonic foliation dip (Figure 14B and 15B).

To compare the distribution of landslides with the average annual precipitation we extracted data from the annual precipitation contour map published by the Taiwan Water Resource Agency (Water Resource Agency, 2015). The results show that for areas underlain by slate (and for landslides of different sizes), landslides occur more frequently between 3000 and $3500 \mathrm{~mm}$ (Figure 16). For areas underlain by schist (and for landslides of different sizes), landslides occur more frequently between 2000 and 
$2500 \mathrm{~mm}$ (Figure 17). Both of the lithological regions show more area is covered by landslides at higher precipitation than at lower precipitation.

The results show that landslides tend to occur in the areas with steeper slope and higher precipitation, however, the value of $\theta_{\mathrm{D}}$ also plays an important role in the landslide distribution. In general, more landslides in the slate region occurred in the lower $\theta_{\mathrm{D}}$ areas and more landslides in the schist regions occurred in the higher $\theta_{\mathrm{D}}$ area.

\section{DISCUSSION AND CONCLUSION}

The result presented above suggest that the landslides in the slate tend to occur in the areas with lower $\theta_{\mathrm{D}}$ whereas landslides in the areas underlain by schist tend to occur where $\theta_{\mathrm{D}}$ is higher, and thus we propose this is a significant result of understanding the role of tectonic cleavage in the distribution of landslides.

To better understand the relation between cleavage dip and the distribution of landslides, we analyzed three smaller areas, each with a different degree of cleavage development; schist, well developed slate and weakly developed slate. In the area underlain by schist, the frequency of all landslides increase with $\theta_{\mathrm{D}}$ (Figure 17A). A similar pattern is observed for the entire field area (Figure 11B). However, the area covered by landslides $\left(D_{L}\right)$ shows a more significant increase with $\theta_{D}$. This result 
indicates that, in areas of schist, landslides tend to occur where cleavage dips opposite to the direction of slope, consistent with the results from the entire field area.

In areas underlain by a well-developed slaty cleavage, the frequency of all landslides increase to $\theta_{\mathrm{D}}$ values of about $90^{\circ}$ and then decrease abruptly at high values of $\theta_{\mathrm{D}}$ (Figure 16B). A similar pattern is observed for the entire field area (Figure 10A). The percentage of area of landslides also decreases abruptly with higher values of $\theta_{\mathrm{D}}$, although the decrease occurs at a lower value of $\theta_{\mathrm{D}}$ (Figure 17B). The significant change of $D_{L}$ value suggests that not only do more landslides occur in areas of lower $\theta_{\mathrm{D}}$, but the accumulated surface area of landslide inventories in the lower $\theta_{\mathrm{D}}$ area is larger than the area in the higher $\theta_{\mathrm{D}}$ area. The results show the landslides in this area tend to occur in the lower $\theta_{\mathrm{D}}$ value area, and the percentage of landslide decreases when the cleavage dip direction is against the slope direction, which is opposite to the landslide pattern in the schist.

Finally, rocks with a lower metamorphism grade underlie the third area and the tectonic fabric is less well developed; a pencil cleavage is more common rather than a well-developed slaty cleavage in the southern part of the Central Range (Ho, 1986; Huang and Byrne, 2014; Lin et al., 2011b; Sung 1991). The histogram shows only a slight difference in $\theta_{\mathrm{D}}$ for all landslides or for relatively large landslides as $\theta_{\mathrm{D}}$ increases (Figure $17 \mathrm{C}$ ). There is also a very slight increase in frequency of area 
covered by landslides at high $\theta_{\mathrm{D}}$ values (e.g., $120^{\circ}$ to $150^{\circ}$ ). Overall, however, we interpret the results from low-grade metamorphic rocks where the tectonic fabric is weak, as showing no relation between $\theta_{\mathrm{D}}$ and the frequency of landslides.

The three more detailed studies suggest two end members: in areas underlain by schist, landslides occur at high $\theta_{\mathrm{D}}$ values whereas in areas underlain by well-developed slate, landslides occur at low $\theta_{\mathrm{D}}$ values. Although there are multiple ways of interpreting these results, one possibility is that the results reflect the shear strength of the dominant fabric anisotropy. For example, the cleavage in slate belt appears to be relatively weak due to the lack of cohesion between the cleavages whereas the cleavage in the schist appears to be relatively strong. These interpretations are consistent with field and thin-section observations that show the cleavage in the slate belt to be penetrative and homogeneous at a regional scale. Interestingly, the rocks in the slate belt appear to be relatively strong as they support essentially all of the high peaks in the Central Range. In contrast, the fabric in the schist is a crenulation cleavage and rarely forms a planar, penetrative fabric, consistent with the low $\theta_{\mathrm{D}}$ values in areas with few landslides. The dominance of landslides at high $\theta_{\mathrm{D}}$ values in the schist may reflect the generally steeper east dipping slopes along the east flank of the range. Finally, areas underlain pencil cleavage, which represents a poorly developed fabric with a weak anisotropy and shows no 
correlation with the distribution of landslides. We suggest, therefore, slope failure in the schist might be dominated by the hill slopes gradient, so it has less relation to the weak bedding or cleavage surface. The landslides in the slate with pencil cleavage have different pattern because the rock is relative homogeneous and the cleavage is not continuous enough to be a weak sliding plane.

Both detailed and regional analysis of landslides and tectonic fabrics suggest the following conclusion: landslides underlain by slate, with a well-developed cleavage, tend to occur in the areas with small $\theta_{\mathrm{D}}$ values, whereas landslides in areas underlain by schist where multiple cleavages are present tend to occur in the areas with large $\theta_{D}$ values, and, finally, in areas with a poor-developed cleavage, landslide distributions have no preferred $\theta_{\mathrm{D}}$ value. We therefore propose that the $\theta_{\mathrm{D}}$ can be a useful tool in understanding the probability of landslide occurrences in metamorphic terrains and could help in estimating the volume of erodible material in a mountain range.

\section{ACKNOWLEDGEMENTS}

We acknowledge David Mirakian and Wei-Hao Hsu who helped with field work and data collection and we appreciate support from Chia-Yu Lu, National Taiwan University, and Li-Jan Sun, United Geotech Inc., for providing the cleavage orientation

data. Yu-Chung Hsieh, Central Geological Survey, Ministry of Economic Affairs, 
Taiwan (R.O.C.) kindly provided assistance with the landslide catalog. We also thank Jean Crespi at the University of Connecticut, Jonathan Gourley at the Trinity College, and Jonathan Lewis at Indiana University of Pennsylvania who shared ideas and suggestions. The research was supported by the National Science Foundation (Tectonics Program and the Office of International Science and Engineering) grants EAR-1220453, EAR-0711353, and the Ministry of Science and Technology, Taiwan (R.O.C.) grant 103-2116-M-002-031-MY3. The authors also appreciate two anonymous reviewers for their critical reviews and constructive comments.

\section{REFERENCE}

Chang, K.-J., Taboada, A., Chan, Y.-C., 2005. Geological and morphological study of the Jiufengershan landslide triggered by the Chi-Chi Taiwan earthquake. Geomorphology 71, 293-309.

Chen, C.-H., Ho, H.-C., Shea, K.-S., Lo, W., Lin, W.-H., Chang, H.-C., Huang, C.-S., Lin, C.-W., Chen, G.-H., Yang, C.-N., Lee, Y.-H., 2000. Geologic Map of Taiwan. Central Geological Survey, MOEA, Taiwan.

Chen, C.-H., Ke, C.-C., Wang, C.-L., 2009. A back-propagation network for the assessment of susceptibility to rock slope failure in the eastern portion of the Southern Cross-Island Highway in Taiwan. Environmental geology 57, 723-733.

Chen, R.-F., Chan, Y.-C., Angelier, J., Hu, J.-C., Huang, C., Chang, K.-J., Shih, T.-Y., 2005a. Large earthquake-triggered landslides and mountain belt erosion: the Tsaoling case, Taiwan. Comptes Rendus Geoscience 337, 1164-1172.

Chen, W.-S., Chen, Y.-C., Yu, N.-t., Yen, I.-C., Yang, B. C.-C., Shih, T.-S., 2005b. Stratigraphic and Tectonic Geomorphic Studies along the Chao Chou Fault, Southern Taiwan-Reevaluating Fault Characteristics and Location. Special Publication of the Central Geological Survey 16, 75-90. 
Chigira, M., 1992. Long-term gravitational deformation of rocks by mass rock creep. Engineering Geology 32, 157-184.

Crespi, J., Chan, Y.-C., Swaim, M., 1996. Synorogenic extension and exhumation of the Taiwan hinterland. Geology 24, 247-250.

Dadson, S. J., Hovius, N., Chen, H., Dade, W. B., Hsieh, M.-L, Willett, S. D., Hu, J.-C., Horng, M.-J., Chen, M.-C., Stark, C. P., Lague, D., Lin, J.-C., 2003. Links between erosion, runoff variability and seismicity in the Taiwan orogen. Nature 426, 648-651.

Dadson, S. J., Hovius, N., Chen, H., Dade, W. B., Lin, J.-C., Hsu, M.-L., Lin, C.-W. Horng, M.-J., Chen, T.-C., Milliman, J., Stark, C. P., 2004. Earthquake-triggered increase in sediment delivery from an active mountain belt. Geology 32, 733-736.

Del Gaudio, V., Pierri, P., Wasowski, J., 2003. An approach to time-probabilistic evaluation of seismically induced landslide hazard. Bulletin of the Seismological Society of America 93, 557-569.

Del Gaudio, V., Wasowski, J., 2004. Time probabilistic evaluation of seismically induced landslide hazard in Irpinia (Southern Italy). Soil Dynamics and Earthquake Engineering 24, 915-928.

Fisher, D. M., Willett, S., Yeh, E.-C., Clark, M. B., 2007. Cleavage fronts and fans as reflections of orogen stress and kinematics in Taiwan. Geology 35, 65-68.

Guzzetti, F., Peruccacci, S., Rossi, M., Stark, C. P., 2008a. The rainfall intensity-duration control of shallow landslides and debris flows: an update. Landslides 5, 3-17.

Guzzetti, F., Ardizzone, F., Cardinali, M., Galli, M., Reichenbach, P., Rossi, M., 2008b. Distribution of landslides in the Upper Tiber River basin, central Italy. Geomorphology 96, 105-122.

Ho, C.-S., 1986. A synthesis of the geologic evolution of Taiwan. Tectonophysics 125, $1-16$.

Hovius, N., Stark, C. P., Chu, H.-T., Lin, J.-C., 2000. Supply and removal of sediment in a landslide-dominated mountain belt: Central Range, Taiwan. The Journal of Geology 108, 73-89.

Hu, H.-N., Liu, H.-D., 1987. Geologic Road Map from Meishan to Yakou along the Southern Cross-Island Highway. Central Geological Survey, Taipei, Taiwan, R.O.C. 
Huang, C., Byrne, T. B., 2014. Tectonic evolution of an active tectonostratigraphic boundary in accretionary wedge: An example from the Tulungwan-Chaochou Fault system, southern Taiwan. Journal of Structural Geology 69, 320-333.

Huang, C.-C., Lee, Y.-H., Liu, H.-P., Keefer, D. K., Jibson, R. W., 2001. Influence of surface-normal ground acceleration on the initiation of the Jih-Feng-Erh-Shan landslide during the 1999 Chi-Chi, Taiwan, earthquake. Bulletin of the Seismological Society of America 91, 953-958.

Hung, J.-J., 2000. Chi-Chi earthquake induced landslides in Taiwan. Earthquake Engineering and Engineering Seismology 2, 25-33.

Jibson, R. W., 1996. Use of landslides for paleoseismic analysis. Engineering geology 43, 291-323.

Jibson, R. W., Keefer, D. K., 1989. Statistical analysis of factors affecting landslide distribution in the New Madrid seismic zone, Tennessee and Kentucky. Engineering Geology 27, 509-542.

Lee, C.-T., 1977. Structural geology of Likuan region, South Cross Island Highway (In Chinese). National Taiwan University, Taipei, Taiwan, R.O.C.

Lee, J.-C., Chu, H.-T., Angelier, J., Chan, Y.-C., Hu, J.-C., Lu, C.-Y., Rau, R.-J., 2002. Geometry and structure of northern surface ruptures of the $1999 \mathrm{Mw}=7.6$ Chi-Chi Taiwan earthquake: influence from inherited fold belt structures. Journal of Structural Geology, 173-192.

Lin, C.-W., Lin, M.-L., Chang, C.-P., Wu, M.-C., Wang, T.-T., Chen, T.-C., 2010. Investigation and Analysis for Geologically Sensitive Areas in National Preservation Domain Program - Geological susceptibility analysis in damage area struck by Morakot typhoon (1/3) 243 pp., Central Geological Survey, MOEA, Taiwan.

Lin, C.-W., Chang, W.-S., Liu, S.-H., Tsai, T.-T., Lee, S.-P., Tsang, Y.-C., Shieh, C.-L., Tseng, C.-M., 2011a. Landslides triggered by the 7 August 2009 Typhoon Morakot in southern Taiwan. Engineering Geology 123, 3-12.

Lin, C.-W., Lin, W.-H., Kao, M.-C., 2011b. Chaozhou, Explanatory text of the geologic map of Taiwan on scale 1: 50000. Central Geological Survey, MOEA, Taiwan.

Lin, C.-W., Lin, M.-L., Chang, C.-P., Wu, M.-C., Wang, T.-T., Chen, T.-C., 2011c. Investigation and Analysis for Geologically Sensitive Areas in National Preservation Domain Program - Geological susceptibility analysis in damage area 
struck by Morakot typhoon (2/3) 360 pp., Central Geological Survey, MOEA, Taiwan.

Lin, C.-W., Lin, M.-L., Chang, C.-P., Wu, M.-C., Wang, T.-T., Chen, T.-C., 2012. Investigation and Analysis for Geologically Sensitive Areas in National Preservation Domain Program - Geological susceptibility analysis in damage area struck by Morakot typhoon (3/3) 496 pp., Central Geological Survey, MOEA, Taiwan.

Lin, W.-H., 1999. On The Laonunghsi Fault - A Boundary Fault Between the Paleogene and the Neogene Strata, Southern Taiwan. Bulletin of the Central Geological Survey 12, 1-24.

Malamud, B. D., Turcotte, D. L., Guzzetti, F., Reichenbach, P., 2004. Landslides, earthquakes, and erosion. Earth and Planetary Science Letters 229, 45-59.

Romeo, R., 2000. Seismically induced landslide displacements: a predictive model. Engineering Geology 58, 337-351.

Stark, C. P., F. Guzzetti, 2009. Landslide rupture and the probability distribution of mobilized debris volumes, Journal of Geophysical Research 114, F00A02, doi:10.1029/2008JF001008.

Stark, C. P., Hovius, N., 2001. The characterization of landslide size distributions. Geophysical Research Letters 28, 1091-1109.

Sung, Q., 1991. Hengchun Peninsula, Explanatory text of the geologic map of Taiwan on scale 1: 50000. Central Geological Survey, MOEA, Taiwan.

Sung, Q., Lin, C.-W., Lin, W.-H., Lin, W.-C., 2000. Chiahsien, Explanatory text of the geologic map of Taiwan on scale 1: 50000. Central Geological Survey, MOEA, Taiwan.

Tang, C.-L., Hu, J.-C., Lin, M.-L., Angelier, J., Lu, C.-Y., Chan, Y.-C., Chu, H.-T., 2009. The Tsaoling landslide triggered by the Chi-Chi earthquake, Taiwan: insights from a discrete element simulation. Engineering Geology 106, 1-19.

Teng, L. S., 1990. Geotectonic evolution of late Cenozoic arc-continent collision in Taiwan. Tectonophysics 183, 57-76.

Water Resource Agency, Ministry of Economic Affairs, Taiwan (R.O.C.), 2015. http://eng.wra.gov.tw/ct.asp?xItem $=48142 \&$ CtNode $=7674($ accessed 07.21.15) 
Wieczorek, G. F., 1996. Landslide Triggering Mechanisms. Landslides: Investigations and Mitigations, A.K. Turner and R.L. Schuster (Eds.), Transportation Research Board, Special Report 247, pp.76-90.

Yu, S.-B., Cheng, H.-Y., Kuo, L.-C., 1997. Velocity field of GPS stations in the Taiwan area. Tectonophysics 274, 41-59. 


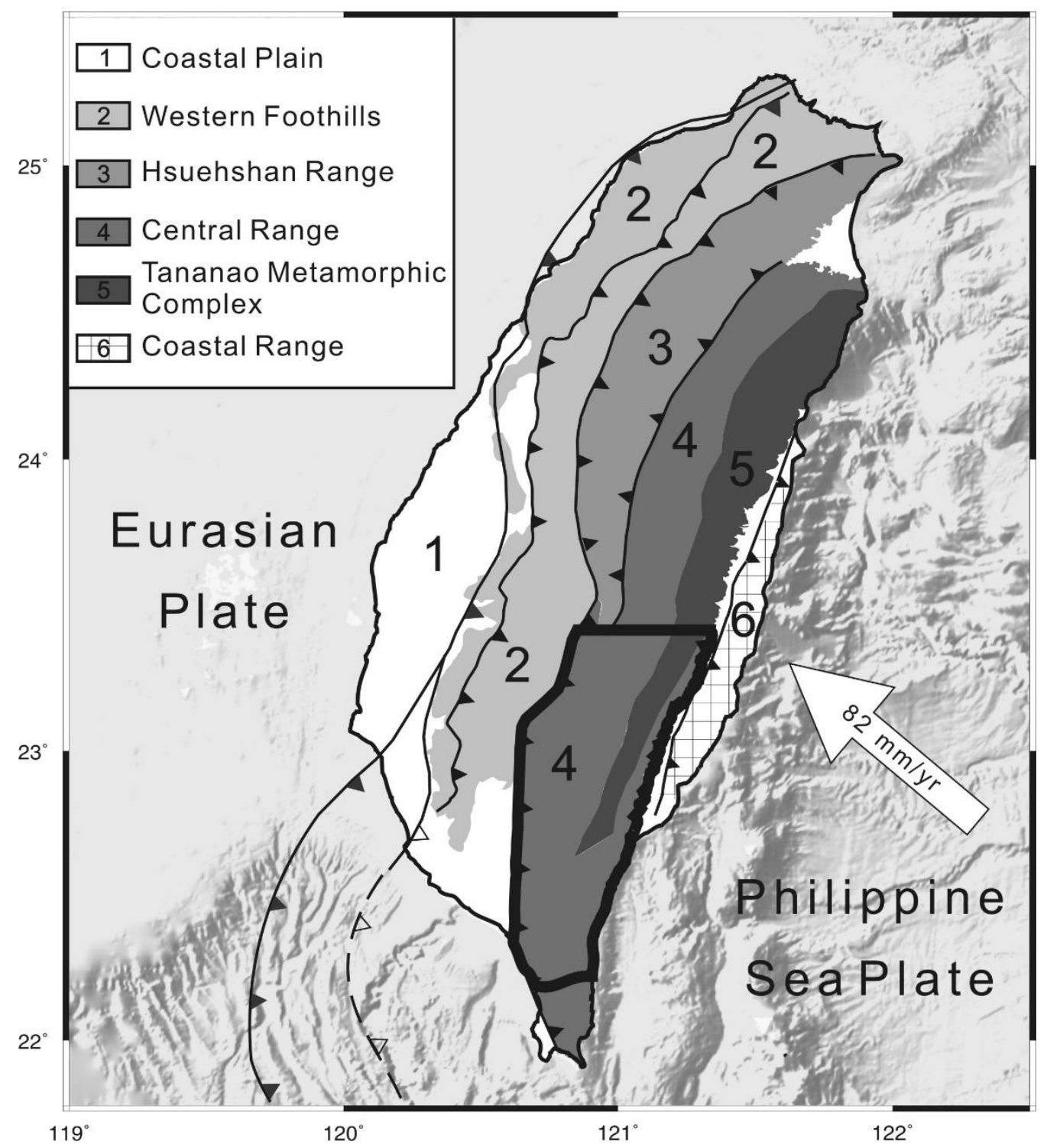

Figure 1. Tectonostratigraphic terranes of Taiwan modified from Lee et al. (2002). $1=$ Coastal Plan; 2 = Western Foothills; 3 = Hsuehshan Range; 4 = Central Range; 5 = Tananao Metamorphic Complex; $6=$ Coastal Range. The Central Range is composed of sub-belts of slate and the Tananao Metamorphic Complex is composed of mostly various composition of schist. The thick, solid line outlines the study area. The white arrow shows the convergent direction and rate of the Philippine Sea Plate relative to the Eurasian Plate (station, S01R, Yu et al., 1997). 


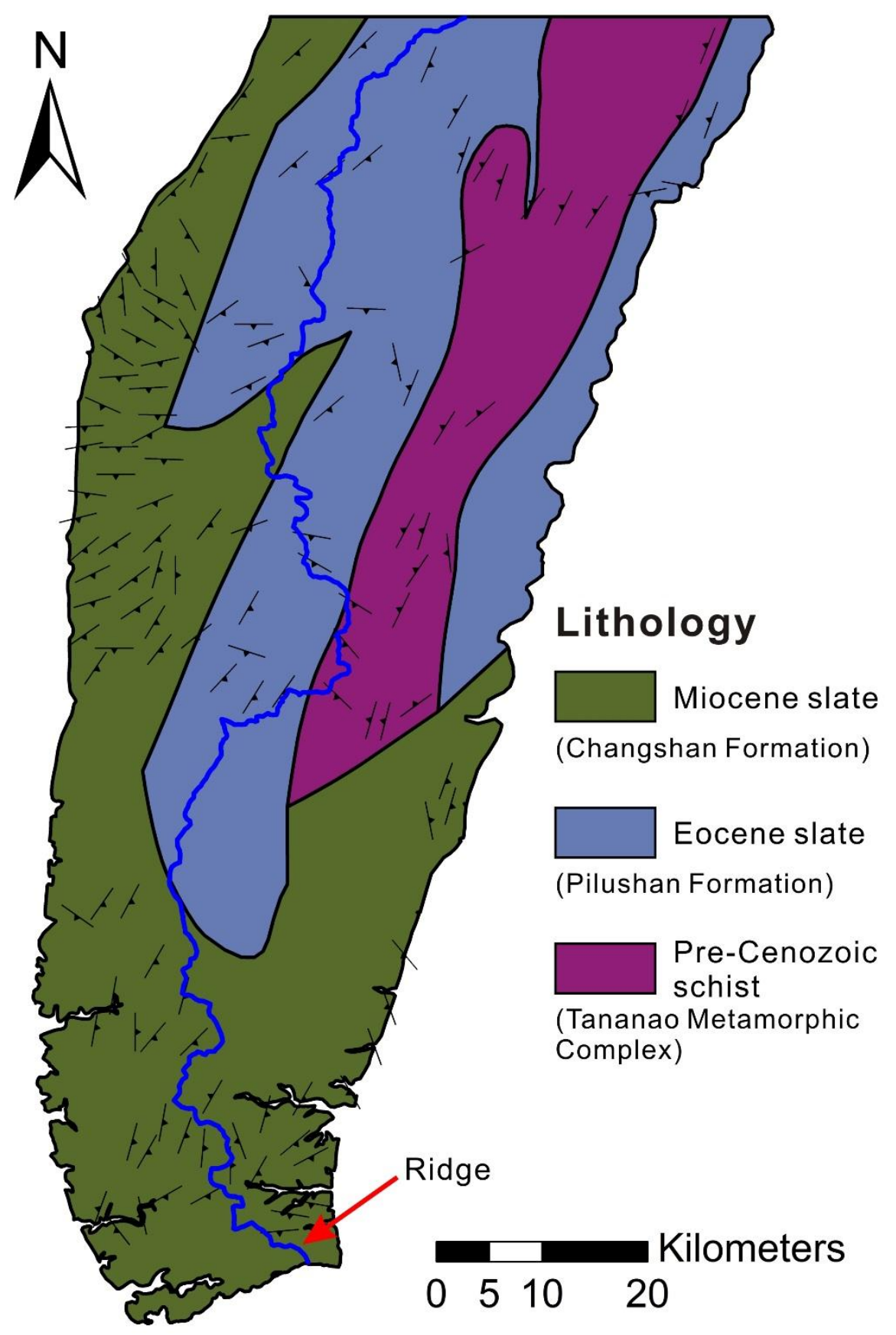

Figure 2. Geological map of study area modified from Chen et al. (2000). The slate region contains Changshan Formation (Miocene slate) and Pilushan Formation (Eocene slate). The schist region represents the Tananao Metamorphic Complex. The blue line marks the ridge crest. 


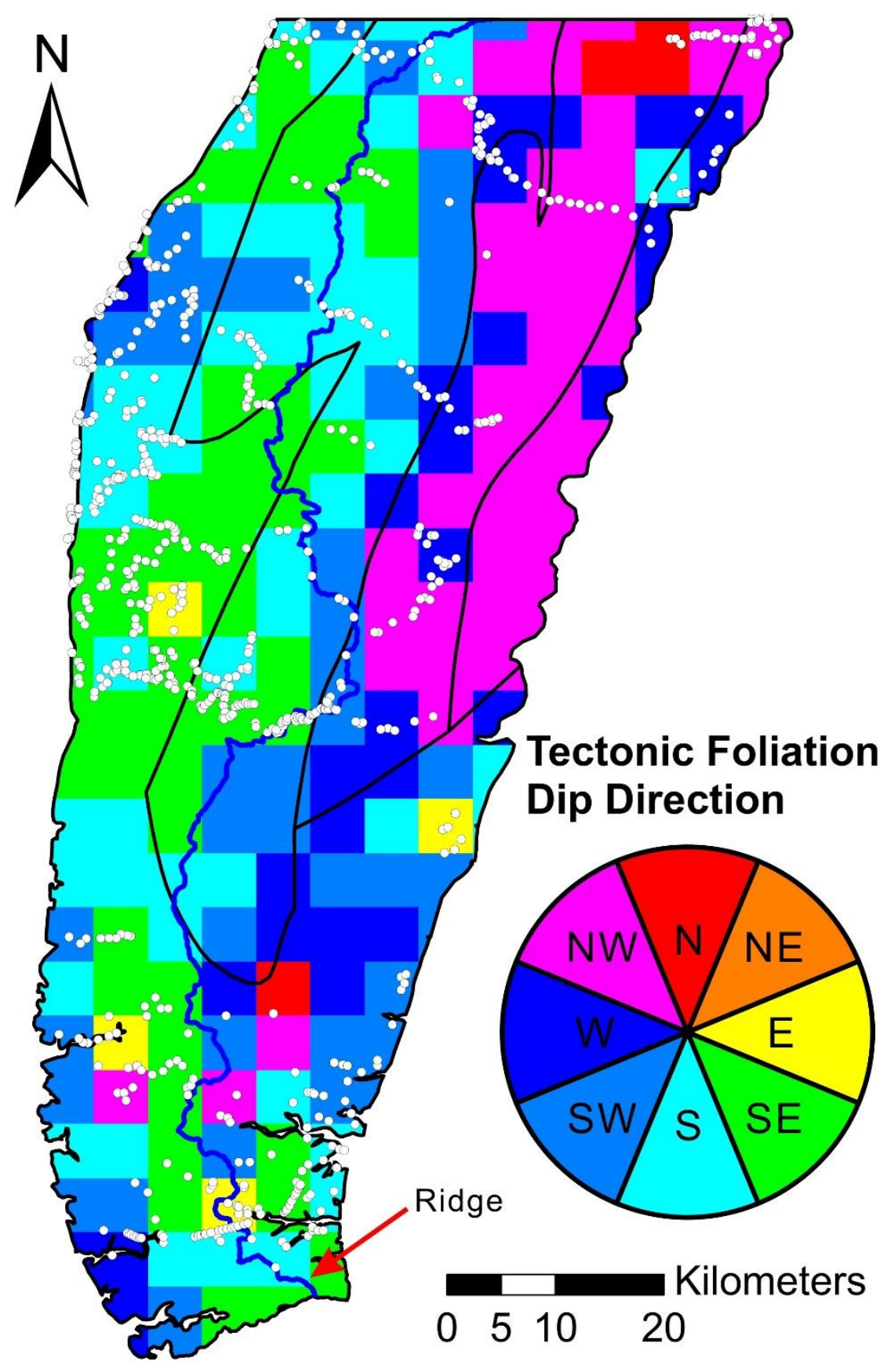

Figure 3. Map of dip direction of tectonic foliation. White circles are the tectonic foliation measurement data locations. Note the foliation in the schist region and a strip of slate east of schist mostly dip to the west. The cleavage in the slate unit west of schist mostly dips to south and southeast while the cleavage of in the slate south of the schist mostly dips to southwest to west. 


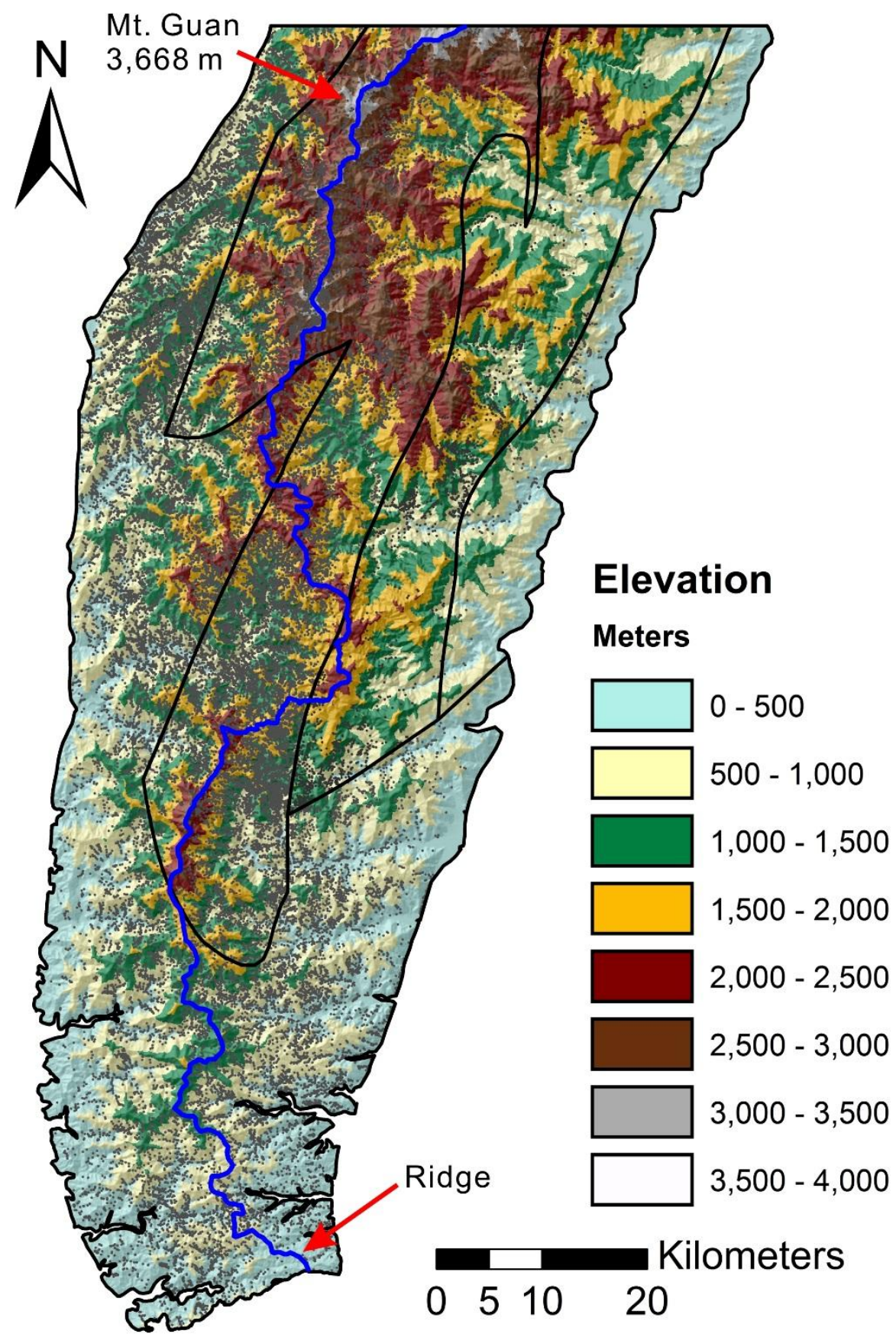

Figure 4. Map of elevation and landslide centroid locations. Gray dots are the centroid point of each landslide inventory. There are 38,686 landslides in the study area, including 36,664 landslides are in the slate region and 2,022 landslides in the schist region. Mt. Guan (3,668 m) is the highest peak in the study area. 


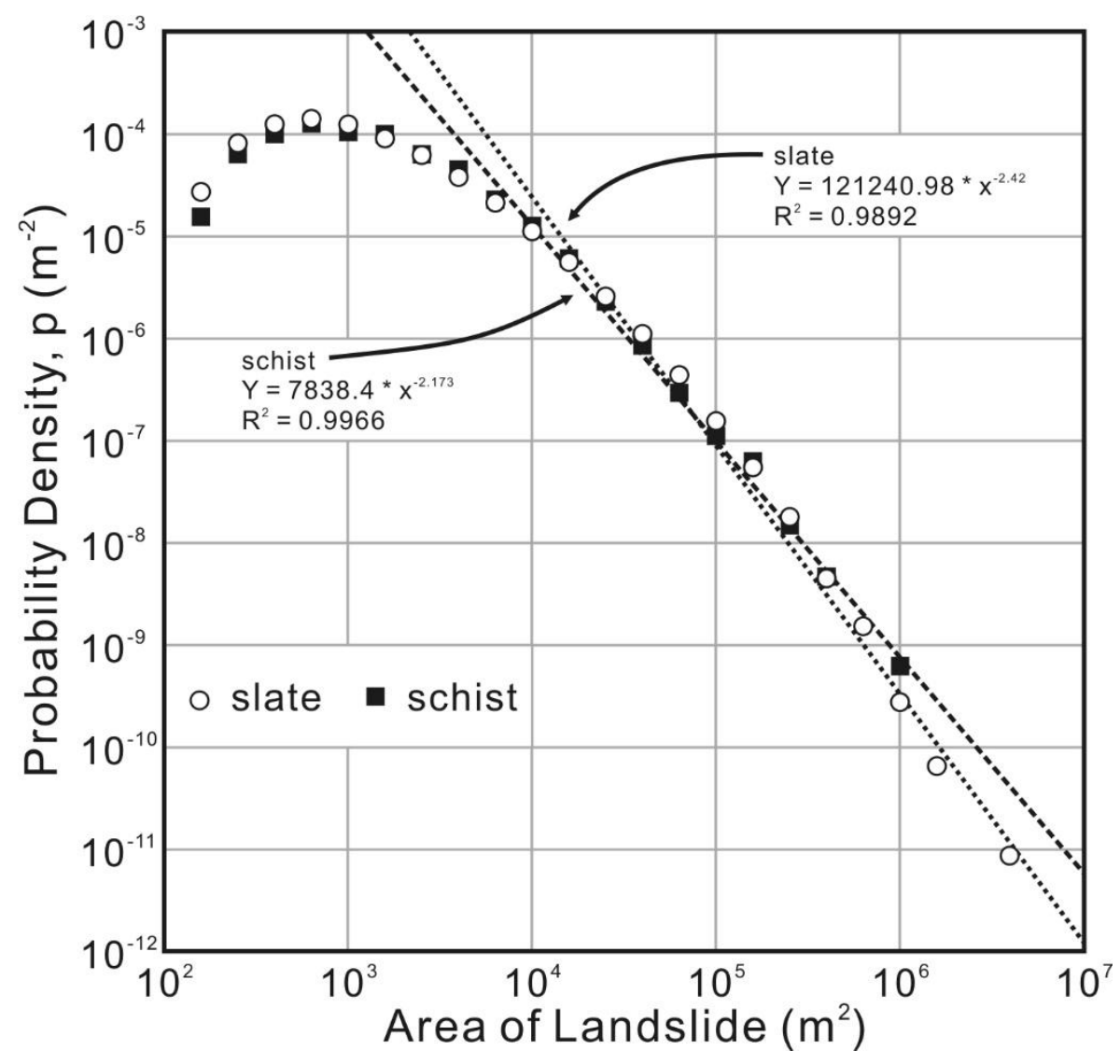

Figure 5. Landslide probability density plot. The power law equation is based on the tails of the two curves. Note the similarity in the curves from the slate and schist. 


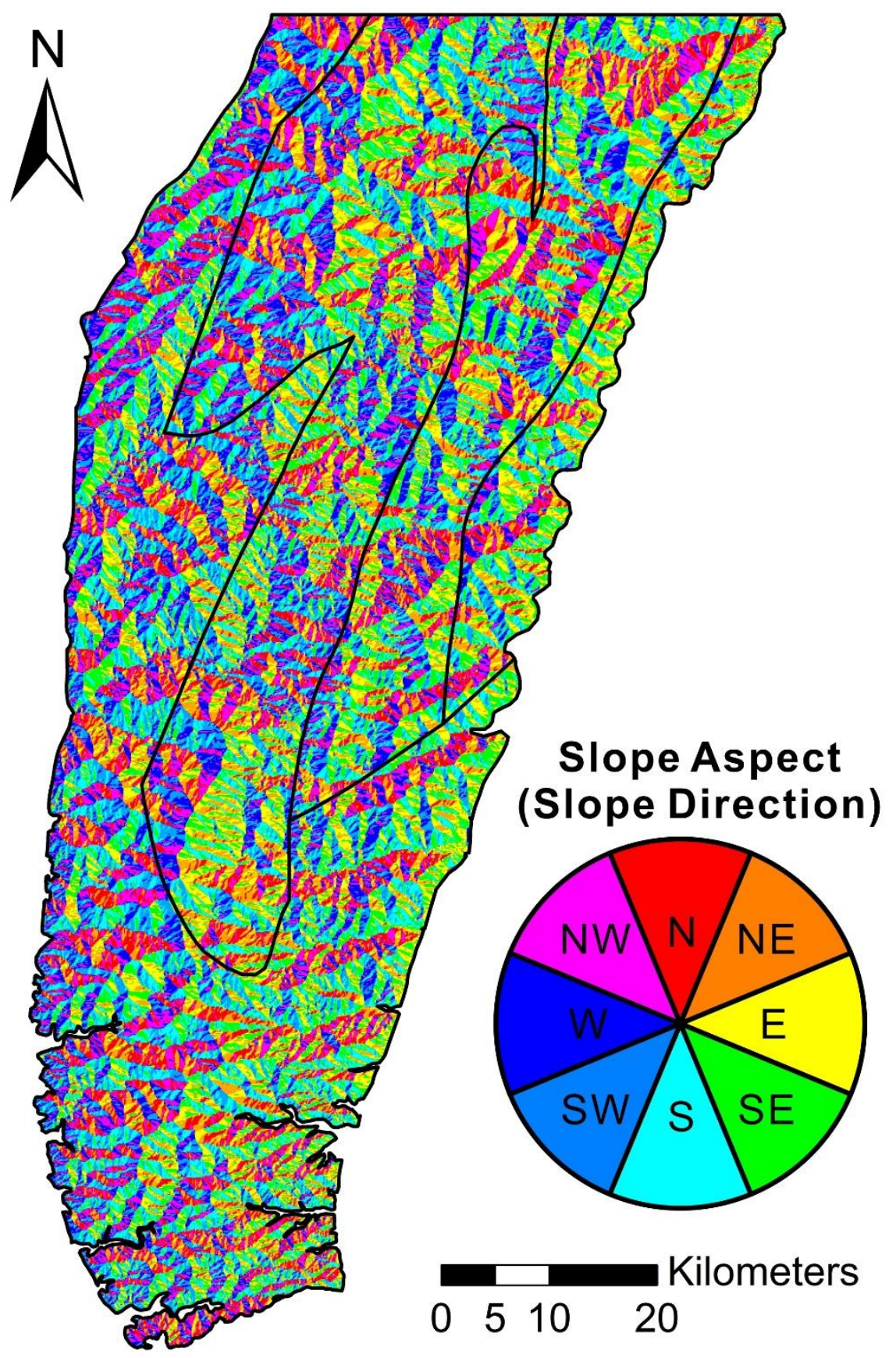

Figure 6. Map of slope aspect (slope direction). 

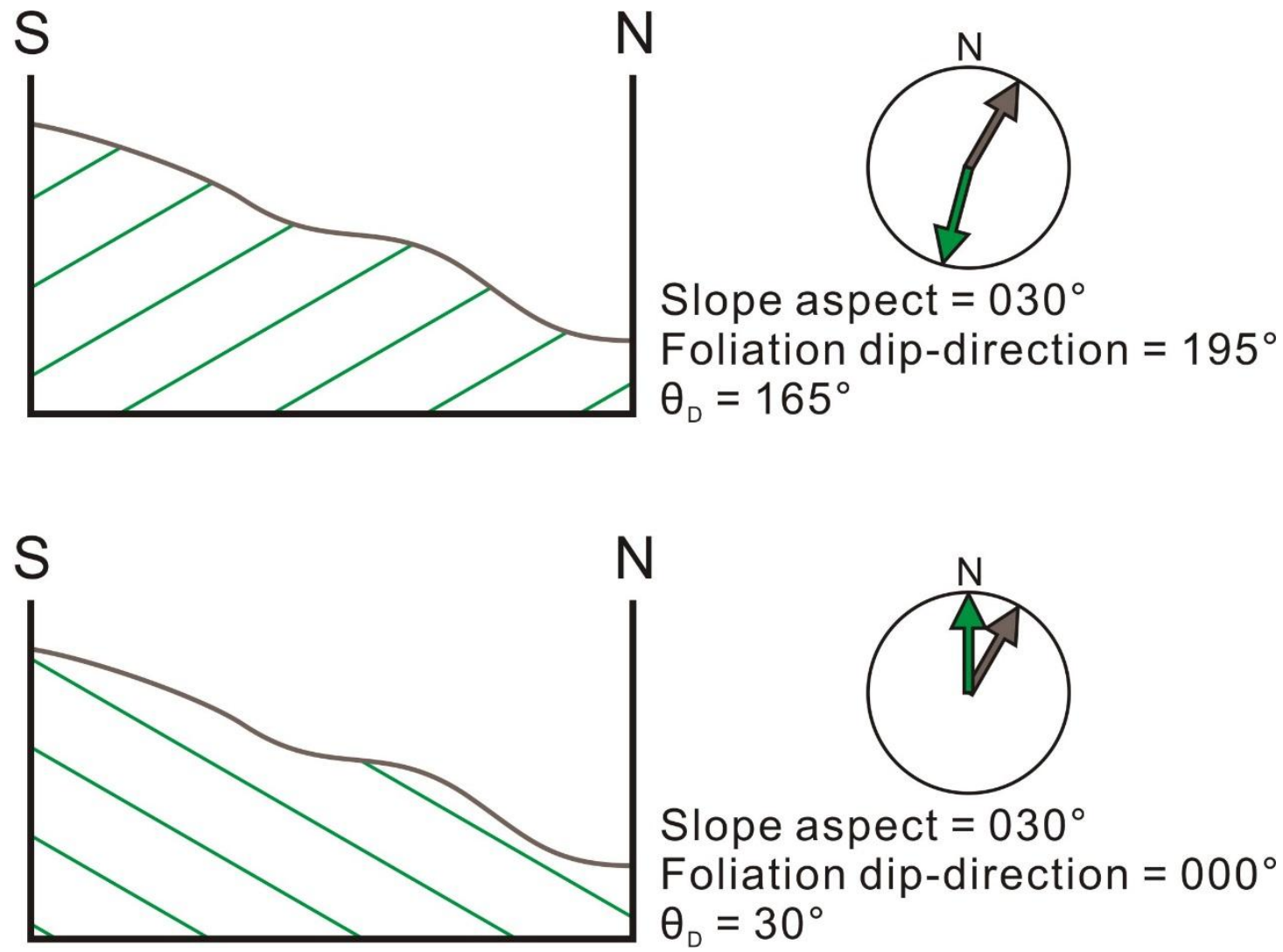

Figure 7. Illustration of the calculation of $\theta_{D}$. The upper figure is an example of high $\theta_{D}$, values and the lower figure is an example of low $\theta_{\mathrm{D}}$ values. 


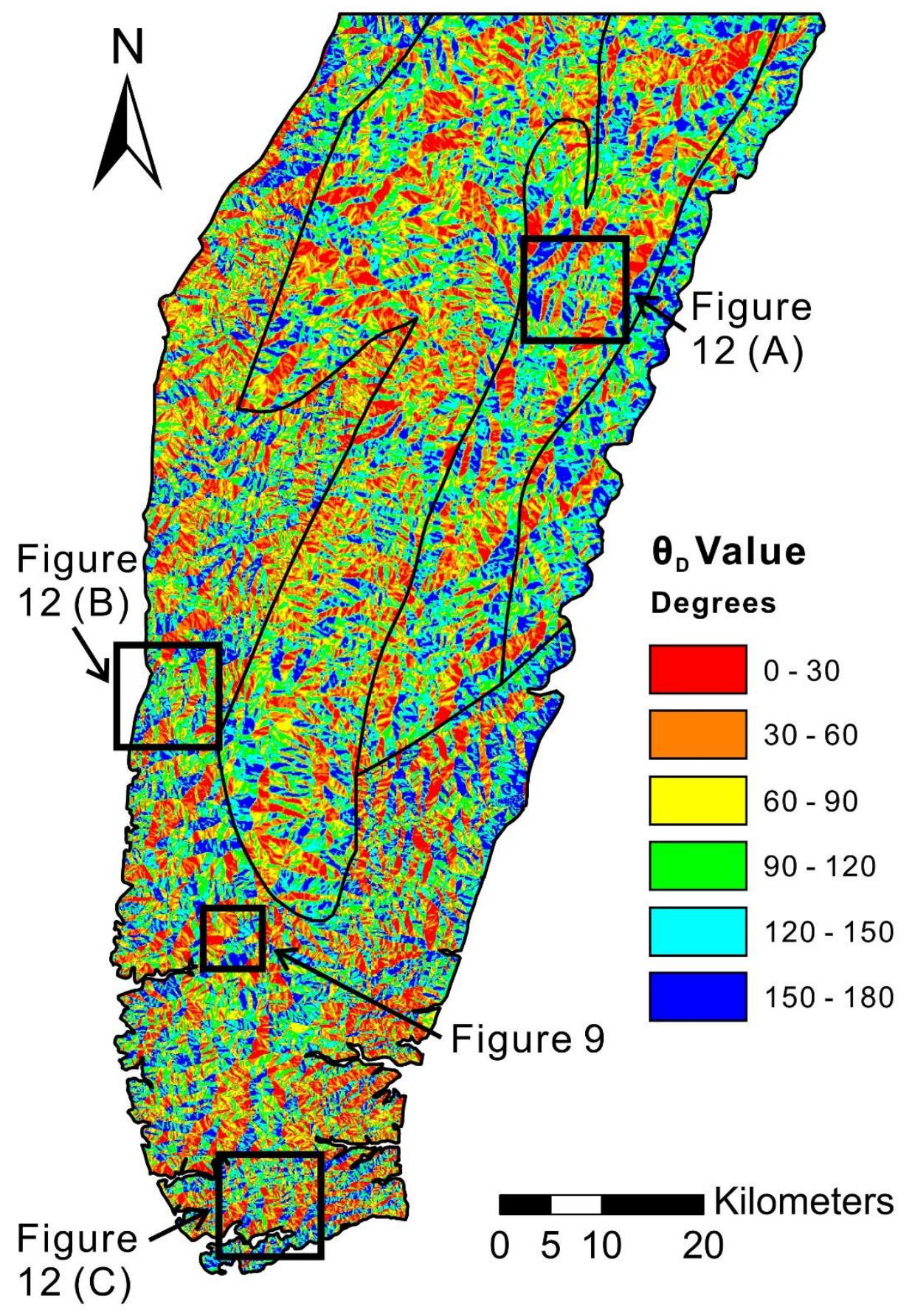

Figure 8. Map of $\theta_{\mathrm{D}}$ values (in degrees). Squares show locations of more detailed studies. See text for discussion. 




Figure 9. The relation between landslide distribution and $\theta_{\mathrm{D}}$ in an area underlain by Miocene slate. The dip direction of foliation in this area is generally to the southeast. (A) Shows the satellite image taken from WorldView-2 on Oct. 20, 2011 with $50 \mathrm{~cm}$ resolution. (B) Shows the digital elevation model (DEM) with $40 \mathrm{~m}$ resolution. (C) Shows the slope map with an overlay of post-Morakot landslide polygons, and (D) is the $\theta_{\mathrm{D}}$ value map overlain with same set of polygons. Note that higher $\theta_{D}$ values dominate the northwest-facing slopes and lower $\theta_{\mathrm{D}}$ values dominate the southeast-facing slopes. Landslides are also more common in areas where slopes face southeast, which correlates with $\theta_{\mathrm{D}}$ low values because cleavage generally dips southeast in this area. 




Figure 10. Histograms of $\theta_{\mathrm{D}}$ values for regions underlain by slate. In (A) white bars show the frequency (in percent) of $\theta_{\mathrm{D}}$ values for the entire region; gray bars show $\theta_{\mathrm{D}}$ for all landslides and black bars show $\theta_{\mathrm{D}}$ for landslides larger than $630 \mathrm{~m}^{2}$. Histograms in (B) show relation of landslide density or area $\left(\mathrm{D}_{\mathrm{L}}\right)$ to $\theta_{\mathrm{D}}$ values. Gray bars show all landslides, and black bars show areas covered by landslides larger than $630 \mathrm{~m}^{2}$. Note that these data show that there are more landslides, and that more area is covered by landslides, in areas where $\theta_{\mathrm{D}}$ ranges from $30^{\circ}$ to $90^{\circ}$. 


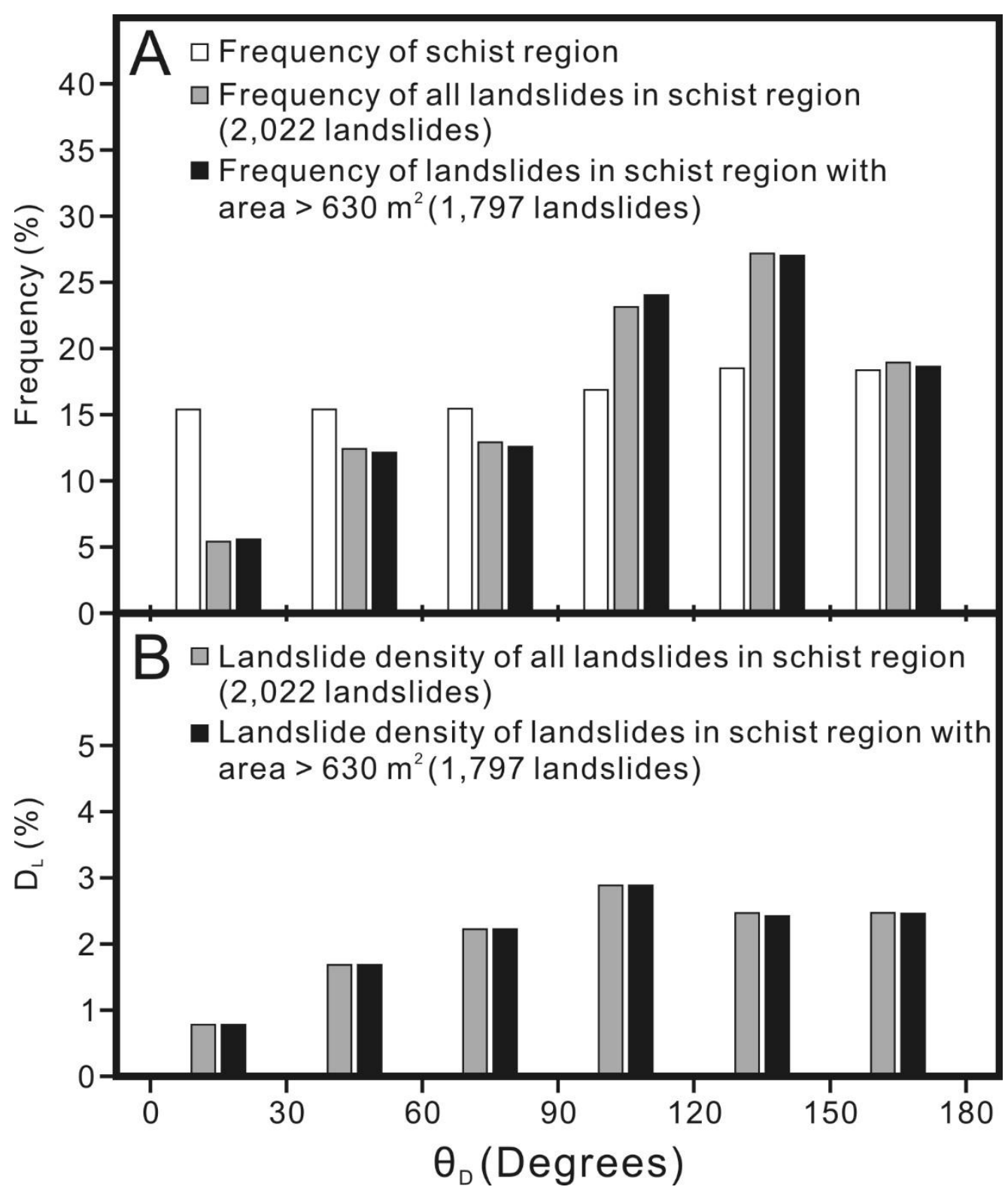

Figure 11. Histograms of $\theta_{\mathrm{D}}$ values for regions underlain by schist. In (A) white bars show the frequency (in percent) of $\theta_{D}$ values for the entire region; gray bars show $\theta_{\mathrm{D}}$ for all landslides and black bars show $\theta_{\mathrm{D}}$ for landslides larger than $630 \mathrm{~m}^{2}$. Histogram in (B) shows relation of landslide density or area $\left(\mathrm{D}_{\mathrm{L}}\right)$ to $\theta_{\mathrm{D}}$ values. Gray bars show all landslides, and black bars show areas covered by landslides larger than $630 \mathrm{~m}^{2}$. Note that these data show that there are more landslides, and that more area is covered by landslides, in areas where $\theta_{\mathrm{D}}$ ranges from $90^{\circ}$ to $150^{\circ}$. 


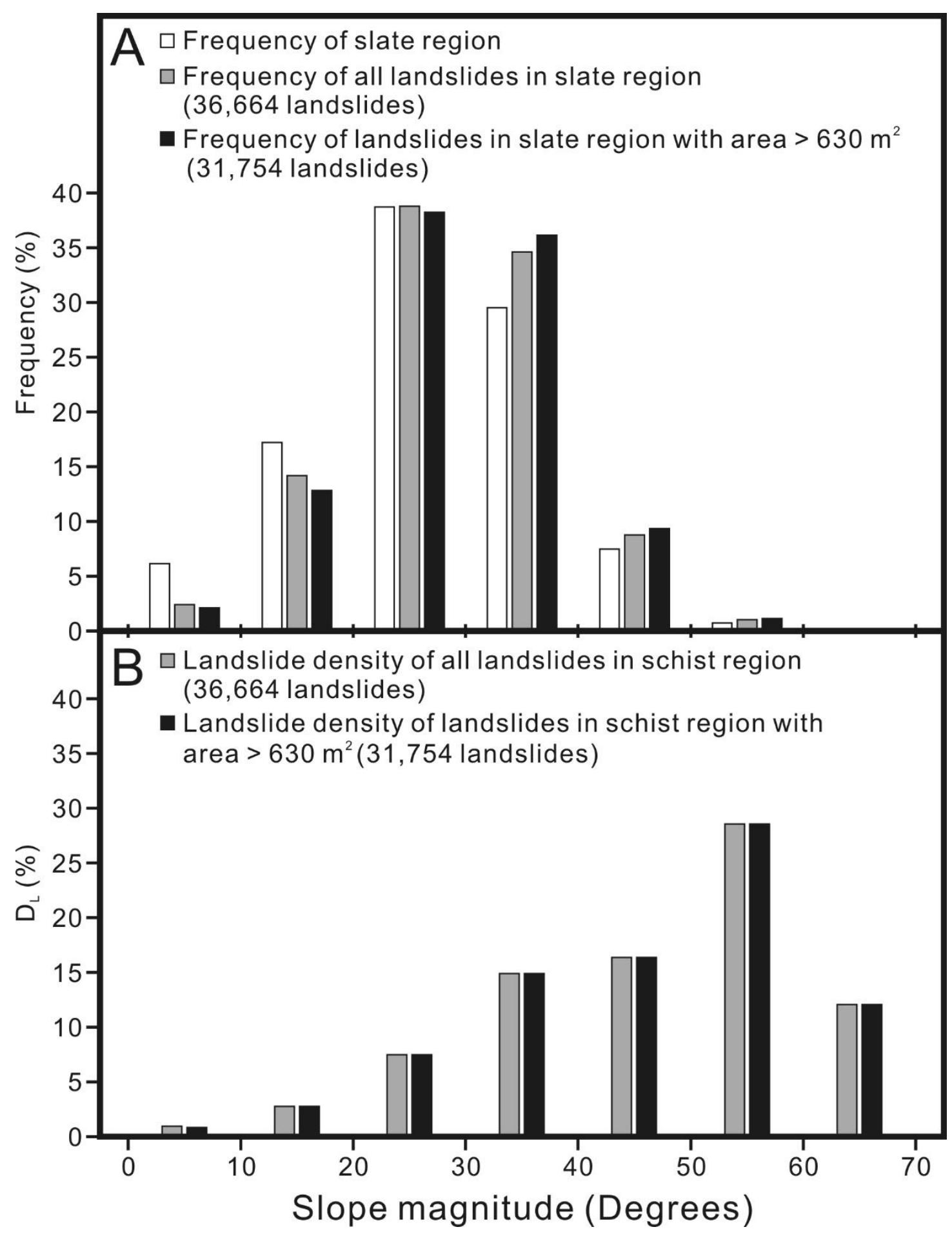

Figure 12. Histograms of slope magnitudes for regions underlain by slate. In (A) white bars show the frequency (in percent) of slope magnitude for the entire region; gray bars show slope magnitude for all landslides and black bars show slope magnitude for landslides larger than $630 \mathrm{~m}^{2}$. Histogram in (B) shows relation of landslide density $\left(\mathrm{D}_{\mathrm{L}}\right)$ to slope magnitude. Gray bars show all landslides, and black bars show areas covered by landslides larger than $630 \mathrm{~m}^{2}$. 


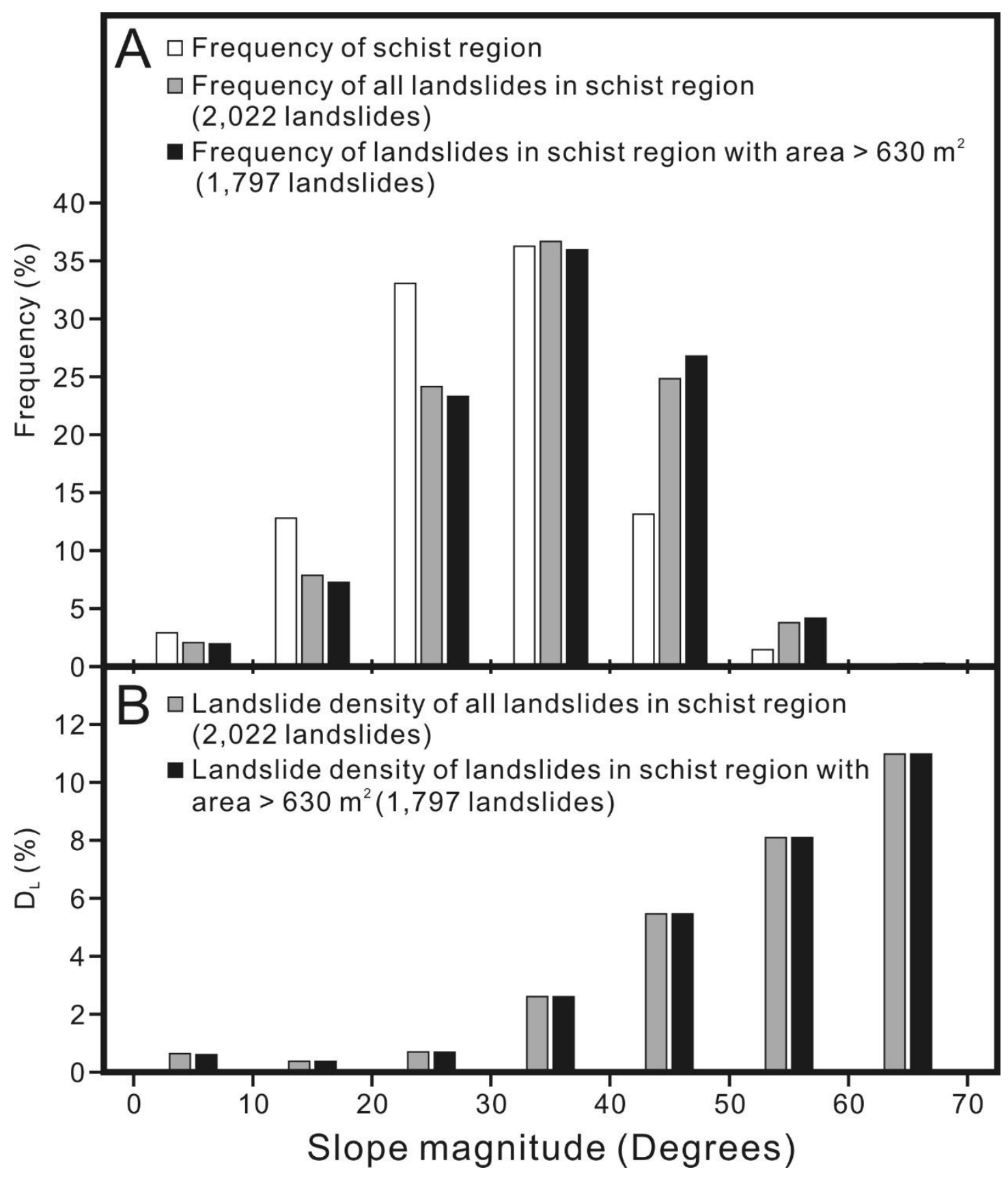

Figure 13. Histograms of slope magnitudes for regions underlain by schist. In (A) white bars show the frequency (in percent) of slope magnitude for the entire region; gray bars show slope magnitude for all landslides and black bars show slope magnitude for landslides larger than $630 \mathrm{~m}^{2}$. Histogram in (B) shows relation of landslide density $\left(\mathrm{D}_{\mathrm{L}}\right)$ to slope magnitude. Gray bars show all landslides, and black bars show areas covered by landslides larger than $630 \mathrm{~m}^{2}$. 


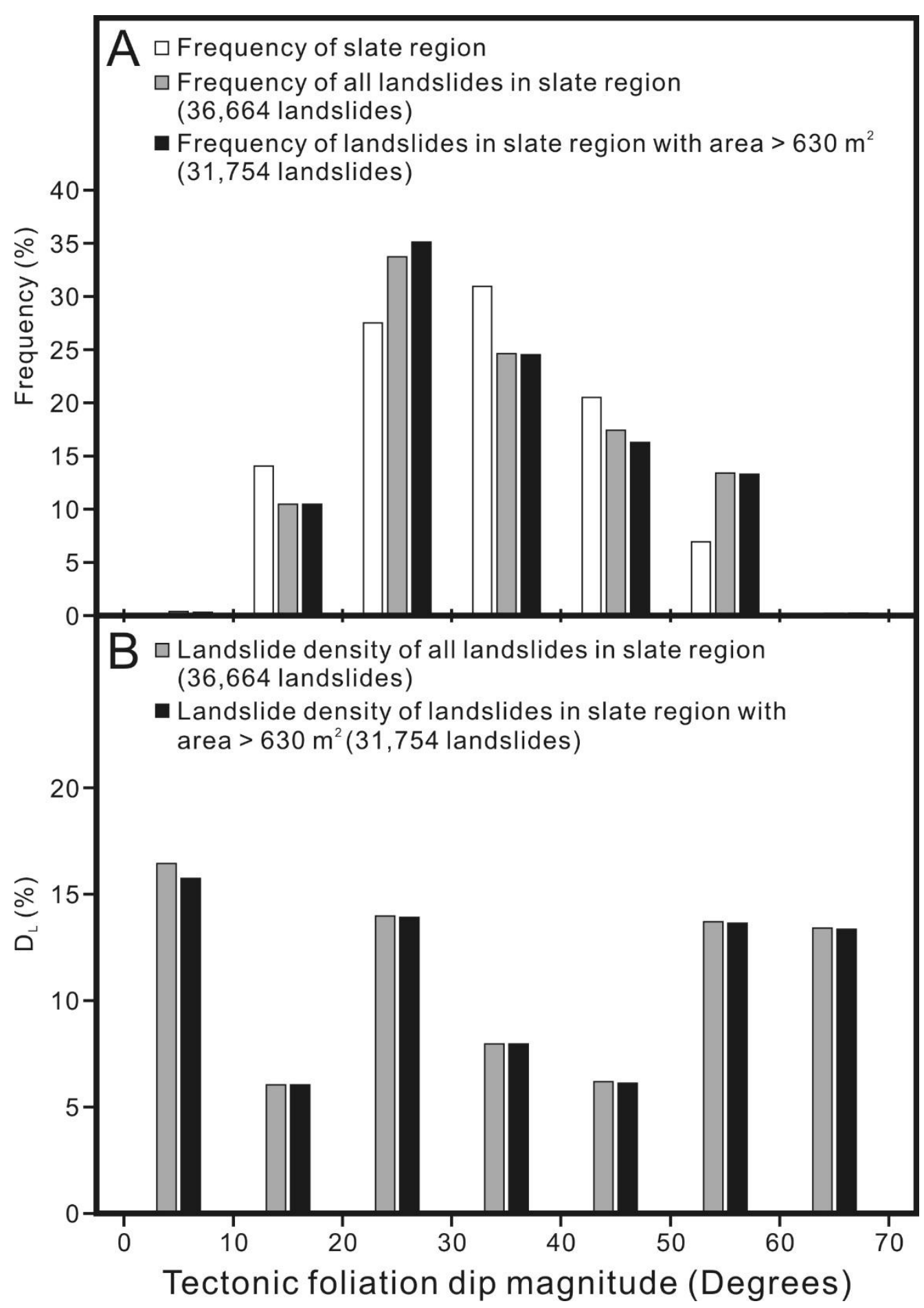

Figure 14. Histograms of dip of tectonic foliation for regions underlain by slate. In (A) white bars show the frequency (in percent) of dip magnitude for the entire region; gray bars show dip magnitude for all landslides and black bars show dip magnitude for landslides larger than $630 \mathrm{~m}^{2}$. Histogram in (B) shows relation of landslide density $\left(D_{L}\right)$ to dip magnitude. Gray bars show all landslides, and black bars show areas covered by landslides larger than 630 $\mathrm{m}^{2}$. 


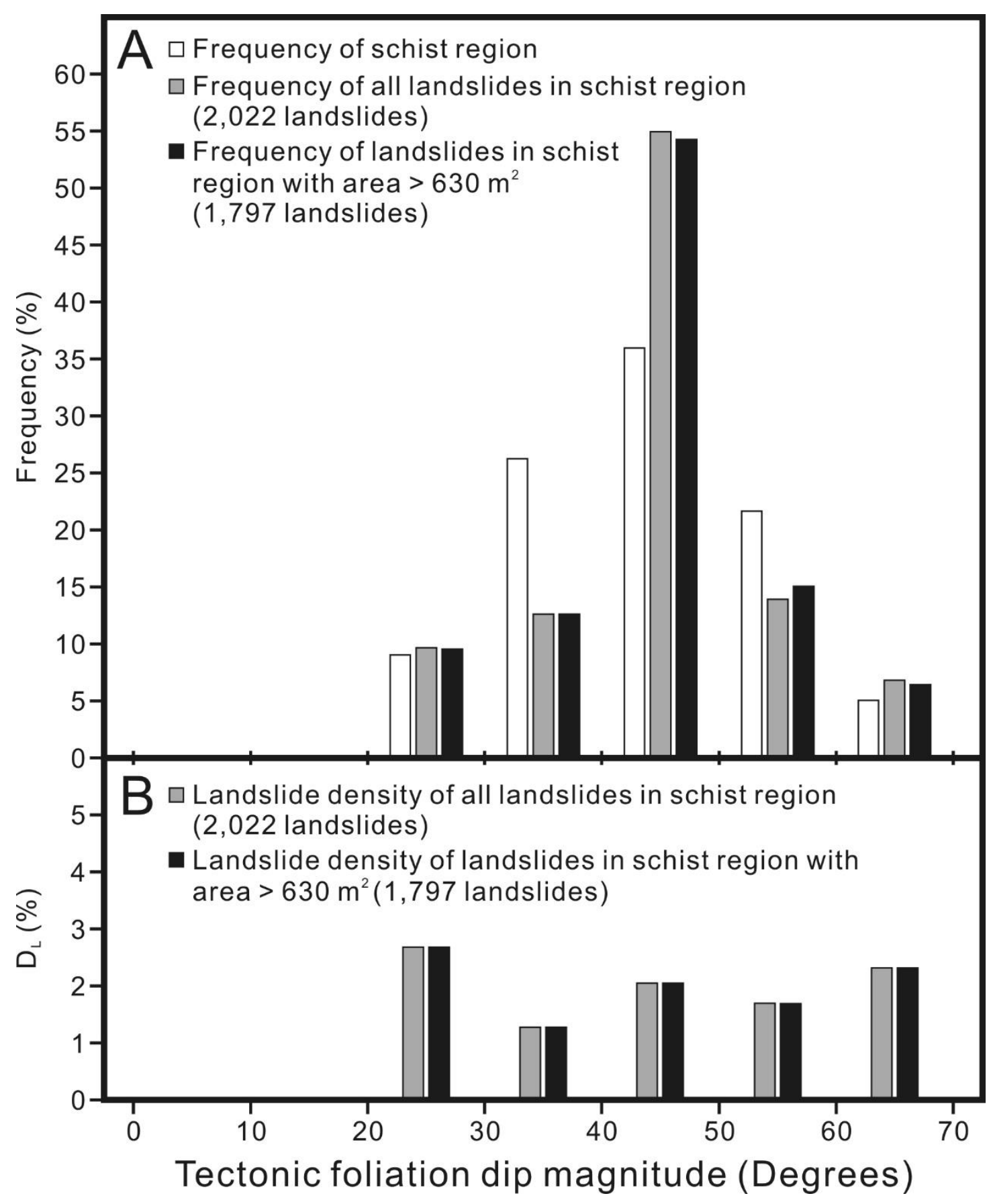

Figure 15. Histograms of the dip of tectonic foliation for regions underlain by schist. In (A) white bars show the frequency (in percent) of dip magnitude for the entire region; gray bars show dip magnitude for all landslides and black bars show dip magnitude for landslides larger than $630 \mathrm{~m}^{2}$. Histogram in (B) shows relation of landslide density $\left(D_{L}\right)$ to dip magnitude. Gray bars show all landslides, and black bars show areas covered by landslides larger than 630 $\mathrm{m}^{2}$. 


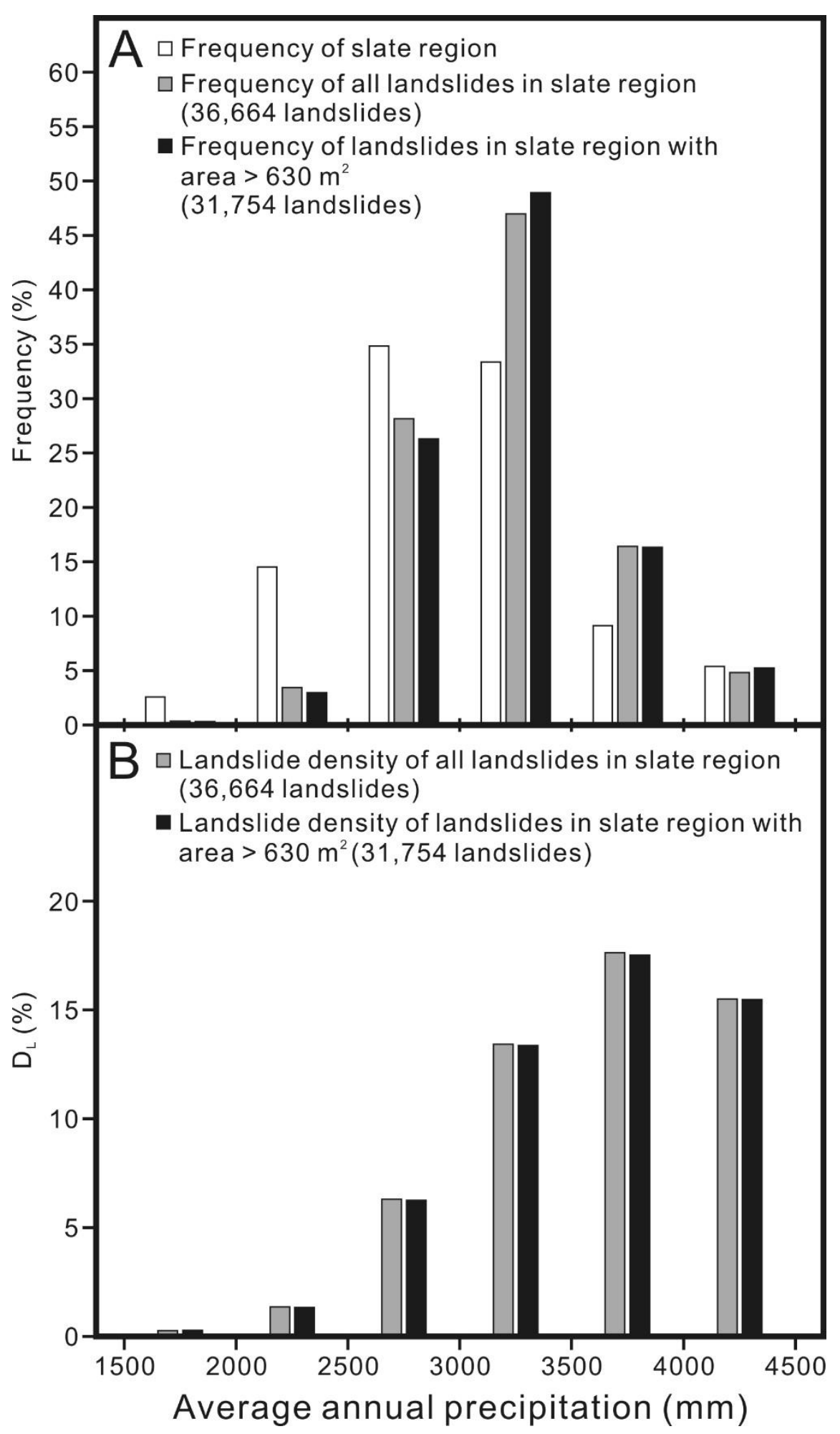

Figure 16. Histograms of the annual average precipitation (1949-2009) for regions underlain by slate. In (A) white bars show the frequency (in percent) of precipitation for the entire region; gray bars show precipitation for all landslides and black bars show precipitation for landslides larger than 630 $\mathrm{m}^{2}$. Histogram in (B) shows relation of landslide density $\left(\mathrm{D}_{\mathrm{L}}\right)$ to precipitation. 


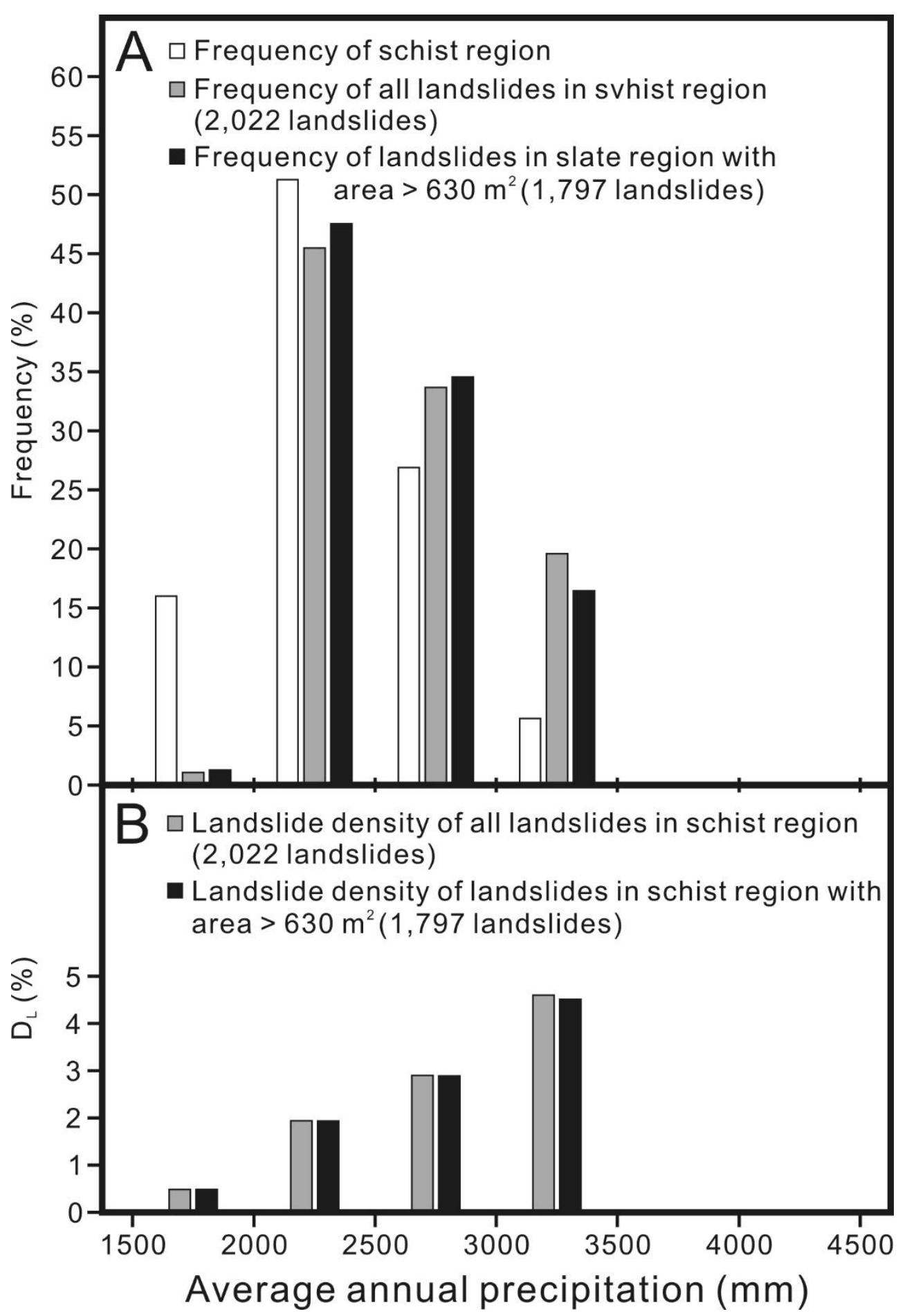

Figure 17. Histograms of the annual average precipitation (1949-2009) for regions underlain by schist. In (A) white bars show the frequency (in percent) of precipitation for the entire region; gray bars show precipitation for all landslides and black bars show precipitation for landslides larger than 630 $\mathrm{m}^{2}$. Histogram in (B) shows relation of landslide density $\left(\mathrm{D}_{\mathrm{L}}\right)$ to precipitation. Gray bars show all landslides, and black bars show areas covered by landslides larger than $630 \mathrm{~m}^{2}$. 


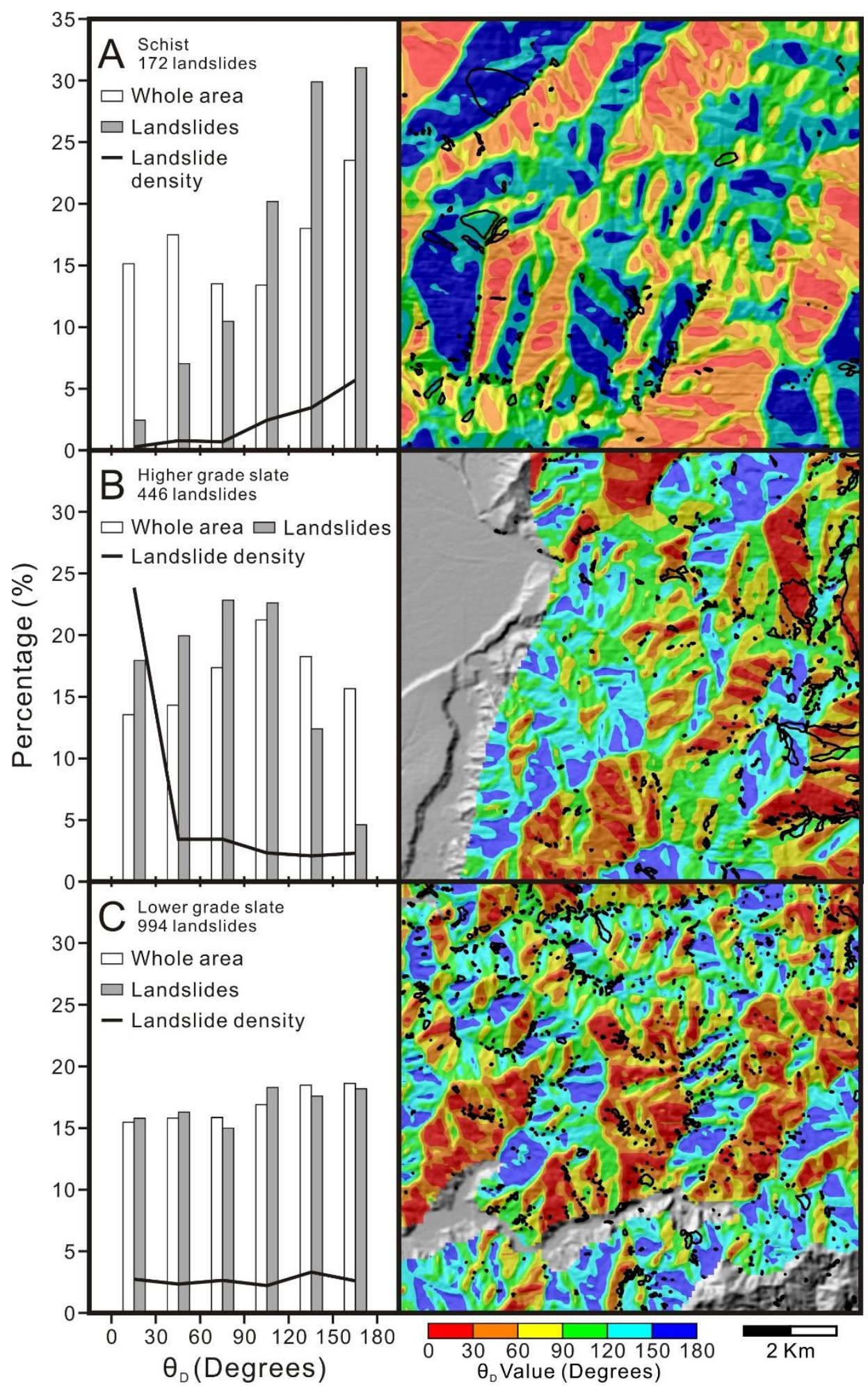

Figure 18. Histograms of landslide frequency and maps of $\theta_{D}$ for three areas with different metamorphic grades and cleavage fabrics, black lines show landslide density $\left(D_{L}\right)$ of all landslides in the selected areas: $(A)$ high grade and irregular cleavage; (B) medium grade and penetrative cleavage and (C) low grade and weak cleavage. 